\title{
Revisiting Matthew's Communities
}

Graham N Stanton

King's College, University of London

\begin{abstract}
The article elaborates upon issues raised in the author's 1992 book, 'A 'Gospel for a New People: Studies in Matthew'. These issues concern the relationship of the first recipients of Matthew's gospel to local Jewish communities and the features of the internal life of the communities for which Matthew wrote. In the light of the complexity of reconstructing the social setting of Matthew's gospel, the article aims at locating it in the broadest possible context within early Judaism and early Christianity.
\end{abstract}

\section{INTRODUCTION}

What political, cultural, and religious assumptions shaped the ways the initial recipients of Matthew's gospel understood the text? Although interpreters differ on the level of priority which should be given to this question, most agree that it must be addressed. But this is far from easy, for it raises a set of further questions which have been on the agenda of careful students of Matthew for a long time. Were the first recipients of this gospel Jews or Gentiles? If some were Jews, and some Gentiles, which group was numerically dominant? Where and when did they live? Did they see themselves as a sect or party within Judaism - perhaps as a reforming movement? Or were many of the original recipients conscious of a recent painful parting from local synagogues? Were their Christian communities racked with internal divisions? If so, is it possible to identify the 'false views' which the evangelist is most concerned about?

In this paper I shall try to go a little further through the same narrow gate and down the difficult path I followed in my 1992 book on Matthew (see Stanton 1992a; see also Stanton 1992b, 1992c, 1996a). I hope to show that some of my more recent work on other early Christian writings, especially Justin Martyr's Dialogue with Trypho, is a further reminder of the value of setting Matthew in the broadest possible context within early Judaism and early Christianity. I shall also respond to some of the recent literature published on Matthew's gospel and to some of the points made by reviewers of my book; in both cases I gratefully acknowledge the stimulus I have received, especially from those whose views differ from my own.

In the first section of this paper I shall suggest that it is much more difficult to reconstruct the social setting of Matthew's gospel than most recent interpreters have supposed. However, all is not lost. In section two I shall return to the relationship of 
the original recipients to local Jewish communities. In my final section I shall look briefly at some features of the internal life of the communities for which Matthew wrote.

\section{GENRE AND GEOGRAPHY}

\subsection{Genre}

The interesting set of essays edited by David Balch (1991) contains surprisingly little reflection on the difficulties Matthew poses for the social historian. Only in Kingsbury's fine 'summing up' is there any reference to the literary genre of Matthew (see Kingsbury 1991:259-269). Kingsbury notes that unlike Ignatius, Matthew has not written a Graeco-Roman letter: 'what Matthew purports to do is to tell neither his own story nor that of his audience but the story of Jesus of Nazareth' (Kingsbury 1991:261).

This important point needs to be underlined firmly, for it has been overlooked by a number of recent writers. The first step in the interpretation of any writing, whether ancient or modern, is to establish its literary genre. I have argued that Matthew (and the other three canonical gospels) are a type or sub-set of Graeco-Roman biography, and this view now has wide support ${ }^{1}$. The primary aim of an ancient biography is simply to set out the Bios of its subject, and I am convinced that it is also the case with Matthew.

Does this aim conflict with my claim that Matthew wrote his gospel as a 'foundation document' for a cluster of Christian communities which saw themselves as a 'new people', minority Christian communities over against both Judaism and the Gentile world at large? I have even suggested that in some respects Matthew is an apology (see Stanton 1992a:378). I do not think that these two proposals are incompatible. Ancient biographies often set out the Bios of their subjects with several different intentions; apologetic and polemical aims are certainly not unknown (see Burridge 1992:149-152). Aune (1988:35) perceptively notes that the unconscious functions of Greco-Roman biography involve the historical legitimation (or discrediting) of a social belief/value system personified in the subject of the biography'. This is precisely the social function I envisage for Matthew's Bios of Jesus (Stanton 1992a:85-145).

As we attempt to uncover the social setting of the original recipients of the gospel, we may well find ourselves wishing that Matthew had written a letter or two. But a moment's reflection will quickly convince us that a Matthean letter might have been almost as problematic as his gospel. Take Paul's letter to the Romans: to what extent is it a systematic exposition of Paul's gospel, and to what extent does it reflect Paul's indirect knowledge of the Christian communities in Rome? Has Paul projected into his letter to Rome, perhaps inadvertently, some of his experiences with Christian communinities elsewhere? The same questions can and should be asked of I Peter, though 
they seem to me to have been given little attention in the recent literature. Similarly Ignatius of Antioch, who used Matthew, which he may sometimes refer to as evं $\alpha \gamma \gamma \varepsilon^{-}$ $\lambda \iota o \nu$ (cf Meier 1991:186). Ignatius wrote six letters to Christian communities in Asia Minor and another to Rome. At many points in those letters it is difficult to know whether his comments reflect his knowledge of the circumstances of the recipients of his letters or his earlier experiences as Bishop in Antioch.

A gospel is not a letter. Since letters do not always provide a clear window onto the social circumstances of the recipients, we must be even more careful with gospels. The examples of Paul, the author of I Peter, and of Ignatius raise two further points which must be considered. Perhaps Matthew did not have first hand information about the circumstances of all the Christian communities for which he wrote. Perhaps, like the author of I Peter, the evangelist wrote for a loose network of communities over a wide geographical area. If this suggestion is plausible, an important corollary follows: Matthew's gospel should not be expected to provide.us with detailed information about the social setting of the first recipients. I am convinced that Matthew's choice of literary genre and the evidence of the text of the gospel itself both point in this direction.

\subsection{Geography}

Where did the first recipients of Matthew's gospel live? Over the years I have made several unsuccessful attempts to persuade myself that Matthew was written in Antioch. So I am pleased to discover that the old consensus is crumbling2. Overman (1990) has suggested Galilee, with claims which are 'extremely cogent' according to Segal (1991). However Segal does not want to reject Syria as the provenance of Matthew, and notes that

Galilee and Syria should be considered as a single geographical area ... at least from the point of view of the development of Jewish and Christian hostility .... Galilee and Antioch were merely two fixed points in a rather loosely confederated group of congregations, united by missionaries who were more or less constantly on the move at first.

(Segal 1991:26-27) $)^{3}$

I concur with this suggestion, which is consistent with the very limited hints which can be gleaned from the text itself. It is also consistent with the broader considerations concerning early Christian-Jewish relationships to which Segal appeals. Matthew's gospel should not be read as if it were a Pauline letter. We should stop supposing that 
the gospel reflects the evangelist's close relationship with one group of Christians in one house church in one particular urban geographical location.

Let me take this latter point a little further. In the Herodian quarter of Jerusalem several splendid villas which were destroyed in $70 \mathrm{CE}$ have recently been excavated. In some respects they are strikingly similar to villas at Pompeii. They remind us of the extent to which Roman fashions in house architecture and interior decoration were mimicked all over the Empire. Even if the Christians to whom Matthew wrote met for worship in a rather grand urban house on the scale of the 'Palatial Mansion' in Jerusalem, or of the House of the Vettii in Pompeii, or of the villa at Sepphoris, or of the villa at Anaploga at Corinth, no more than fifty or so people could have assembled in its largest room (see Avigad 1991:75) ${ }^{4}$. Surely Matthew's carefully crafted, very full account of the Bios of Jesus was not written for such a small group of people: surely we should envisage a loosely linked set of communities over a wide geographical area.

If, as I am arguing, Matthew intended to set out the Bios of Jesus for a number of loosely linked communities, then we should be wary of attempts to link the gospel to a precise set of social, historical, or religious circumstances. Expositions of Matthew's concerns which are based on only one strand of the evidence, or one particular passage, or on an over-confident use of 'transparency' are not likely to be compelling. Anderson (1993) has provided a salutary warning concerning transparency: we must 'resist treating a gospel as an allegory with a one to one correspondence to particular persons or events, an allegory that allows us to see directly through a window into the Matthean community' (Anderson 1993:642-671).

It is difficult to reconstruct the social and religious setting of the first listeners to and readers of Matthew without in effect treating the text as an allegory, and without giving free rein to our own assumptions about several aspects of earliest Christianity. However there is general agreement that in spite of the difficulties, the attempt must be made: an appreciation of the 'horizons of expectation' brought by the initial recipients of a text plays an important part in interpretation.

So how do we proceed? Previously I have suggested one way forward (see Stanton 1992a), though it is certainly not the only way: redaction criticism, and literary and social-scientific approaches all have their place, though they must all be kept under rigorous critical scrutiny. I also insisted that Matthew's gospel should be set as firmly as possible in the context of early Christianity and Judaism. I have not changed my mind on these disputed questions of method, though I am now more wary of the dangers of 'transparency'. However, I do not think it is illegitimate to relate the text cautiously to the life of the communities for which the evangelist wrote. The text itself 
provides some encouragement to do this: there are a number of passages in which readers in the author's own day are addressed directly in asides in the story, and there are several passages which presuppose a post-Easter setting.

\section{EXTERNAL AFFAIRS}

The relationship of Matthew's communities to Judaism has been keenly debated for some time now. Discussion has been vigorous because a decision on this issue influences the interpretation both of many individual passages and also of the sweep of the whole story. In my earlier work on Matthew I tried to assess the various views which have been advanced in modern scholarship, and to set out the reasons why I think that the evangelist is writing to communities which have separated painfully from Judaism but are still defining themselves over against the parent body. I do not propose to rehearse the arguments here. However, since an assessment of the social setting of Matthew's gospel cannot avoid this issue, I shall offer several further considerations in support of my view. At several points I shall be looking over my shoulder at Saldarini's (1994) recently published book. This excellent book is the most sustained defense of a view which I consider to be the main rival to my own: Matthew 'addresses a deviant group within the Jewish community in greater Syria, a reformist Jewish sect seeking influence and power (relatively unsuccessfully) within the Jewish community as a whole' (Saldarini 1994:198).

\subsection{Blurred boundary lines}

At the outset I must mention one respect in which I would now want to modify my position. Further study of Justin's Dialogue with Trypho has convinced me that the relationships of individuals and groups within Matthew's communities to Jewish communities were probably much more varied than I had assumed to be the case.

Justin's Dialogue indicates that in the middle of the second century both Judaism and Christianity were concerned to maintain tight boundaries. Trypho complains that Christians (unlike Jews) do not mark themselves off from pagans (10.3). He also mentions that some Jewish teachers forbid Jews to enter into conversation with Christians - lest they be persuaded by 'blasphemous' Christian claims. (38.1; 112.4). Justin's references to alleged Jewish persecution of Christians also point to Jewish anxiety lest community boundaries be breached.

Justin is concerned to maintain tight boundaries on the Christian side. He will not tolerate Jewish Christians who are not in full fellowship with Gentile Christians. Justin is very sensitive about Jewish Christians who persuade Gentile Christians to keep the law: he suspects that under their influence some Gentile Christians may move over completely to the Jewish polity. 
And yet in spite of the concerns of Trypho and Justin to maintain tight boundaries around Judaism and Christianity, there is movement across both boundary lines. This has happened in the past, and there is an expectation that it will happen in the future. In short, there is keen 'on the ground' rivalry.

Justin's Dialogue suggests that there were different levels of attachment to both communities. On the Jewish side there were proselytes whose status was often ambiguous; would-be proselytes, such as Trypho's companions; other Gentile sympathizers; some Jews who acknowledged Christ, but were not in full fellowship with Gentile Christians; and some former Gentile Christians who had 'gone over' to Judaism.

On the Christian side there were two kinds of Jewish Christians, one acceptable to Justin, and one not. There were also Gentile Christians who seemed likely to 'go over' to the Jewish polity.

No doubt both sides hoped to consolidate the level of commitment of those on the 'fringes' of their communities. From a later period a tradition expresses what is likely to have been the case in Justin's 'school' as well as in synagogues: '.. when the sage takes his seat to expound doctrine, many strangers become proselytes' (CantR 1.15; cf 1.3 and 4.2).

Justin's Dialogue confirms that long after 'Christianity' had emerged as a religious entity quite distinct from Judaism, at 'grass roots' level there was considerable fluidity 5 . This is even more likely to have been the case in Matthew's day, even though it would be rash to suppose that this fluidity is reflected explicitly in the text itself ${ }^{6}$.

\subsection{The crowds}

One of the main pillars in Saldarini's case is his insistence that Matthew's harsh polemic against the various leaders of Israel should not lead us to suppose that Israel as a whole has been rejected, or even that the evangelist and his readers have parted company with their fellow-Jews. Saldarini (1994:38) suggests that 'Matthew meant the crowds to symbolize the Jewish community of his day, which he hoped to attract to his brand of Judaism'. 'The crowds seem to represent the people of Israel who must still be won away from their false leaders' (Saldarini 1994:40).

I accept that Matthew's presentation of the crowds strongly suggests that the evangelist still hopes that individual Jews will be 'won over.' However, a 'one to one' correspondence between the crowds and the Jewish community of Matthew's day is too simplistic 7 .

Matthew's initial presentation of the crowds is subtle: it plays an important but usually overlooked role in his story. Matthew 4:14-16 alerts the reader to the fact that the coming of Jesus will fulfil Scripture (Isaiah 9: 1-2) and be a light for Galilee of the 
Gentiles. The evangelist's summary of the teaching and healing ministry of Jesus in Matthew 4:23-25, which plays such an important part in the structure of the gospel, develops this point. Matthew notes that the fame of Jesus spread throughout Syria. Whether Matthew has in mind the whole Roman province of Syria (so Luz 1985:181, note 16), or a narrower area 'perhaps extending approximately from Damascus to Antioch and on to the east' (so Davies \& Allison 1988:417), Gentiles as well as Jews are certainly in view.

Matthew 4:25, which contains Matthew's first use of ox $\lambda \lambda o$, makes the same point. The large crowds which followed Jesus and which form part of the audience for the Sermon on the Mount, came from Galilee and the Decapolis, as well as Jerusalem and Judaea, and from the Transjordan area. Reference to 'Galilee' may recall 'Galilee of the Gentiles' at Matthew 4:15. This is made probable by Matthew's inclusion of the Decapolis in his list of places from which crowds came. Matthew's readers would certainly have known that the cities of the Decapolis were strongly Hellenistic in character. An important Greek inscription mentions a prefect of the Decapolis in Syria: that is, at the time Matthew wrote, the Decapolis, endowed with a certain autonomy, was attached to the province of Syria (see Rey-Coquais 1992:118). Although Jews lived in Syria and the Decapolis, they were very much in the minority; both regions were known first and foremost as centres of Graeco-Roman culture.

In short, in his initial presentation of the crowds who play such an important role in his story, Matthew hints broadly that they include Gentiles ${ }^{8}$. This is all of a piece with the way the evangelist skilfully reminds his readers ever more insistently that ultimately the story of Jesus has implications for Gentiles as well as Jews. Matthew's crowds, then, do not, 'represent the people of Israel who must still be won away from their false leaders' (Saldarini 1994:40).

Even if we were to grant this point, a sharp distinction between hostile Jewish leaders and 'ordinary' Jewish people open to the claims of followers of Jesus would not necessarily support the proposal that the evangelist and his communities are still within Judaism. Three or four generations later in Justin's day there is a yawning gap between Judaism and Christianity in spite of the blurred boundary lines to which I have referred above. Yet in the opening exchanges between Trypho and Justin in chapters 8 and 9 both claim that the other person has been led astray by false teachers. Trypho claims that Justin has been led astray ( $\dot{\xi} \xi \alpha \pi \alpha \eta \eta \hat{\eta} \nu \alpha \iota)$ by false speeches, and has followed men of no account'. Justin retorts that Trypho has 'obeyed teachers who do not understand the Scriptures, and has prophesied falsely ( $\dot{\alpha} \pi о \mu \alpha \nu \tau \varepsilon v o ́ n \varepsilon \nu \circ \varsigma)$, saying whatever comes into his mind' (9.1). Justin then insists that he wants to show Trypho 
that Christians have not been led astray $(\pi \varepsilon \pi \lambda \alpha \nu \eta \dot{\mu} \mu \varepsilon \alpha)$; the context suggests that false teachers are in mind ${ }^{10}$. Both single out false teachers as responsible for the false stance taken by the other. Both hope that once the sway of the false teachers is shaken off, their rival will be able to change sides.

This is a major theme in the Dialogue. In numerous passages Justin tries to separate Trypho (and 'ordinary' Jews) from Jewish leaders who are hostile to Christian claims ${ }^{11}$. By blaming the leaders for the separation of the two communities, Justin and Trypho leave the door ajar for individuals to change sides: neither expects the other religious community to capitulate completely. I do not think that matters were very different in Matthew's day.

\section{3 $\sigma u \nu \alpha \gamma \omega \gamma \dot{\eta}$ and $\dot{\varepsilon} \kappa \kappa \lambda \eta \eta \iota \alpha$}

Scholars who have insisted that Matthew's gospel does reflect a parting of the ways with Judaism have often appealed to the evangelist's use of $\dot{\varepsilon} \kappa \kappa \lambda \eta \sigma i \alpha$ at Matthew 16:18 and Matthew 18:17. This term, they claim, is used in order to differentiate Matthean sommunities from local synagogues: over against the latter stands the $\dot{\varepsilon} \kappa \kappa \lambda \eta \sigma i \alpha$ founded by Jesus himself and promised divine protection (Mt 16:18). Saldarini $(1994: 7,27,116)$ has set the cat among the pigeons by insisting that it is significant that Matthew has no name for his group. So what about Matthew's use of $\dot{\varepsilon} \kappa \kappa \lambda \eta \sigma i \alpha$ ? Saldarini is well aware that this might be thought to be the Achilles' heel in his case, so he defends his position carefully. He accepts that Matthew probably used ékк $\lambda \eta \sigma i \alpha$ to denote his group in order to differentiate himself from his opponents in the Jewish community (Saldarini 1994:119). Just as the Jewish leaders claimed to lead the

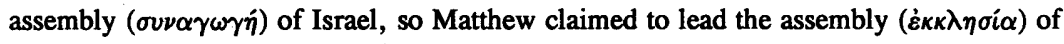
Israel according to the teachings of Jesus. In other words, a general Christian concept of 'church' should not be read into Matthew's usage of $\dot{\varepsilon} \kappa \kappa \lambda \eta \sigma i \alpha$. Matthew's group is a Jesus-centred form of Judaism (Saldarini 1994:119-120).

Now it is the case that many of the approximately one hundred examples of $\dot{\varepsilon} \kappa \kappa \lambda \eta \sigma i \alpha$ in the LXX are synonymous with $\sigma 0 \nu \alpha \gamma \omega \gamma \eta \dot{\eta}$ and that both terms often have a non-technical sense, 'assembly'. However we have no first century evidence that

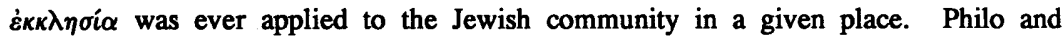
Josephus refer to sabbath meetings of Jews to hear the scriptures read, but they do not

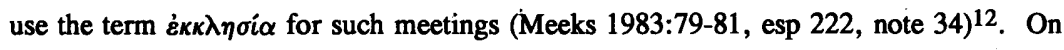
Saldarini's explanation, Matthew's use of $\dot{\varepsilon} \kappa \kappa \lambda \eta \sigma i \alpha$ to denote 'the assembly of Israel according to the teachings of Jesus' would be unique. While this is possible, it is surely much more likely that Matthew's use is dependent, whether directly or indirectly, on Pauline and other early Christian usage ${ }^{13}$. 
On the other hand, we must not suppose that in Matthew's day $\sigma v \nu \alpha \gamma \omega \gamma$ r stood for Judaism over against Christianity, $\dot{\varepsilon} \kappa \kappa \lambda \eta \sigma i \alpha$. I am sure I have occasionally been guilty of that anachronism. I have already noted that the evidence of Justin's Dialogue warns us that in all probability boundary lines were blurred. Justin also reminds us that even three or four generations after Matthew, $\sigma \nu \nu \alpha \gamma \omega \gamma \dot{\eta}$ and $\dot{\varepsilon} \kappa \kappa \lambda \eta \sigma i \alpha$ had not yet become metonyms for Judaism and Christianity, two distinct religions opposed to one another.

There are only two passages in the Dialogue where $\sigma 0 \nu \alpha \gamma \omega \gamma \dot{\eta}$ and $\dot{\varepsilon} \kappa \kappa \lambda \eta \sigma i \alpha$ are juxtaposed, 63.5 and 134.3. Both passages are baffling until one realises that they must be read in the light of 53.4. Dialogue 53 contains Justin's exposition of the entry of Jesus into Jerusalem in the light of Genesis 49:11 and Zechariah 9:9; in the chapter as a whole Matthean phraseology and emphases are prominent. In 53:4 Justin insists to Trypho that the 'beast of burden and the ass's colt' referred to by Zechariah was a 'foretelling of those of your $\sigma v \nu \alpha \gamma \omega \gamma \eta$ ' who should believe on him (Christ), and also of those who should come from the Gentiles'. Here $\sigma v \nu \alpha \gamma \omega \gamma \eta$ is used in a neutral sense to refer to Jewish people, and not to Judaism as a hostile religion over against Christianity.

In 63.5 Justin claims that Psalm 45:6-11 refers to those who believe on Christ, 'as men of one soul and one $\sigma \nu \nu \alpha \gamma \omega \gamma \dot{\eta}$ and one $\dot{\varepsilon} \kappa \kappa \lambda \eta \sigma i \alpha$....' Once again $\sigma v \nu \alpha \gamma \omega \gamma \dot{\eta}$ means simply 'Jewish people'; $\dot{\varepsilon} \kappa \kappa \lambda \eta \sigma i \alpha$, rather unusually, means 'Gentiles'. Justin is stressing the unity of believers in Christ: they include both Jews and Gentiles. Similarly Dialogue 134.3, where Justin is interpreting typologically the story of Jacob, Ieah and Rachel: 'Now Leah is your people $\kappa \alpha i \dot{\eta} \dot{\eta} \sigma \nu \alpha \gamma \omega \gamma \dot{\eta}$, but Rachel is our $\dot{\varepsilon} \kappa \kappa \lambda \eta \sigma i \alpha$. And Christ still serves for these, and for his servants that are in both'. Once again Justin is using $\sigma v \nu \alpha \gamma \omega \gamma \dot{\eta}$ and $\dot{\varepsilon} \kappa \kappa \lambda \eta \sigma i \alpha$ to denote Jewish people on the one hand, and Gentiles on the other, from both of whom come believers in Christ.

Matthew's relationship to Judaism will be debated for a long time to come. Anthony Saldarini is making me think hard about many points, but I have to confess that I have not changed my mind. The sweep of Matthew's story persuades me that the evangelist wrote his gospel as a 'foundation document' for a cluster of Christian communities. Although 'on the ground', boundaries were sometimes blurred, the evangelist and most of the original recipients of the gospel saw themselves as a 'new people', over against both local synagogues and the Gentile world at large. The gospel contains a whole series of 'legitimating answers' for the 'new people'. It responds to polemic from the parent body which was directed at all the central moments in its own 'new' story: the virginal conception of Jesus (Mt 1:18-25), the teaching of Jesus concerning the law (Mt 5:17-48, esp Mt 5:17), the exorcisms of Jesus (Mt 9:34; 10:25; $12: 24$, 
27), his prophetic teaching (Mt 27:63), his resurrection (Mt 28:12-15; see Stanton 1992a:237-242; 1994a:166-182). And even more fully and prominently, the gospel defends vigorously the distinctive convictions and self-understanding of the "new people.'

Matthew's $\dot{\varepsilon} \kappa \kappa \lambda \eta \sigma i \alpha$ has its own entrance rite, baptism in the triadic name (Mt 28:19). Matthew's account of the last supper (Mt 26:26-30) reflects liturgical usage and thus confirms that Matthew's $\dot{\varepsilon} \kappa \kappa \lambda \eta \sigma i \alpha$ had its own distinctive act of worship. Whereas the reading of torah and instruction in it were central in synagogues, in the $\dot{\varepsilon} \kappa \kappa \lambda \eta \sigma i \alpha$ the words of Jesus were very prominent. Matthean Christians are sent by the Risen Christ to make disciples of all nations by teaching them to keep all the 'commands' of Jesus. No doubt this was taken to include instruction in torah as interpreted by Jesus, but Matthew 28:20 strongly suggests that in community life, the commands of Jesus took precedence: they were the filter through which torah was viewed, not vice versa. The self-understanding of the $\dot{\varepsilon} \kappa \kappa \lambda \eta \sigma i \alpha$ is quite distinct from that of the synagogue.

\section{INTERNAL AFFAIRS}

Discussions of the social setting of Matthew's gospel have concentrated on the relationships of Matthew's communities to local synagogues and have often neglected internal affairs. The evangelist directs as much vigorous polemic at followers of Jesus as he does at the religious leaders. I shall sketch the terminology used to refer to groups of disciples. As we shall see, it is distinctive within earliest Christianity. But it is rarely noted that most of Matthew's terminology for groups of disciples did not survive. Why not? Most of Matthew's other emphases influenced second century Christianity strongly.

\subsection{Patterns of ministry}

One strand in Matthew's story stands out more clearly than in the other gospels. For Matthean Christians the story of Jesus offered a model of discipleship and ministry. In numerous redactional passages Matthew emphasizes that the proclamation, healing actions, meekness, humility, and compassion of Jesus are all models for his disciples and, we may add, for his followers in later times. There is also a darker side to the lines of correspondence Matthew carefully draws between Jesus and his disciples. This is expressed in a number of passages, most notably and powerfully in the important redactional saying Matthew has added at Matthew 10:25b: 'If they have called the master of the house Beelzebul, how much more will they malign those of his household'. In the preceding verses the disciples have been warned that they are to expect rejection and persecution. Now they are told that they are to expect even 
greater abuse than that heaped upon Jesus himself, abuse which has already been referred to explicitly at Matthew 9:3414. Since the sayings in the second part of Matthew 10 refer so clearly to the post-Easter period (see Luz 1983:100), Matthew 10:25 implies that the persecution of Christians in the evangelist's own day will include this form of abuse. In other words, the accusation that both Jesus and his followers are in league with the prince of demons is not a matter of past history; for Matthew and his readers it is a present experience. Even though Jesus is set apart as the Son of God, the Davidic Messiah, the Kyrios, his story is also the disciples' story.

These themes influenced later Christian thought very considerably. However, this was not the case with the terminology which is used in Matthew to refer to all the followers of Jesus, and to particular groups. The demise of this terminology is puzzling.

Of the terms used to refer to disciples of Jesus, oi $\mu \iota x \rho o$ is the most intriguing. The phrase first appears at Matthew 10:42, the climax of a set of three sayings of Jesus at the end of the Mission Discourse. The opening saying (Mt 10:40), which is a Matthean development of a $Q$ logion, draws an exact parallel between the authority given to Jesus by God and the authority given to (all) the disciples by Jesus: 'whoever receives you receives me, and whoever receives me receives the One who sent me'. Matthew 10:41, which is probably the evangelist's own expansion of the preceding logion, refers to the rewards which will be given to those who welcome a prophet and a righteous person. Matthew 10:42 is Matthew's version of Mark 9:41; among the changes he makes is the introduction of the phrase oi $\mu \iota \kappa \rho$ i to refer to the disciples ${ }^{15}$. From the immediate context (and from Matthew's use of the phrase at Mt 18:6, 10, and 14; and his use of the superlative at Mt 25:40 and 45) it is clear that oi $\mu \iota x \rho o$ is Matthew's characteristic way of referring to all disciples, not a special inner group.

The first reference to oi $\mu \iota \kappa \rho o i$ in the fourth discourse is striking. At Matthew 18:6

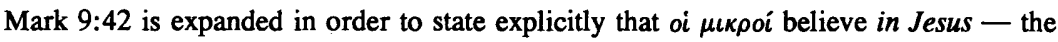
only time such a phrase is used in the synoptic traditions ${ }^{16}$. Here the evangelist uses a post-Easter confessional phrase - a broad hint that readers in the evangelist's own day are being addressed.

Who are the 'prophets' and the 'righteous', terms probably introduced in Matthew 10:41 by Matthew himself? The latter is the more difficult term, since it is not used elsewhere by the Evangelist to refer to disciples. As we shall see in a moment, 'prophets' are a particular group within the Matthean communities. Hence it is likely that 'the righteous' are too; the parallel reference in Matthew 10:41 to a reward appropriate for 'a prophet' and for a 'righteous person' strongly suggests that this is the case. The verb $\delta \varepsilon x \propto \mu \alpha \iota$ (and the wider context) implies 'welcome with hospitality', so both the prophets and the righteous are probably itinerant followers of Jesus. But it is impossible to say more about the role of 'the righteous' with any confidence ${ }^{17}$. 
There is rather more evidence for prophets within Matthean circles. Matthew's warnings against the activity of false prophets in Matthew 7:18-23 presuppose the activity of true prophets, an activity which is referred to at Matthew 5:12 (implicitly); Matthew 10:41 and 23:34. Matthew 7:22 confirms that the false prophets prophesied, exorcised demons, and performed healing miracles. Matthew does not indulge in polemic against these activities: prophets are rejected only when they fail to 'do the will of the heavenly Father'.

One further special group of disciples is referred to. At Matthew 23:34 the scribes and Pharisees are told that they will reject and persecute 'the (Christian) prophets and wise men and scribes' who will be sent to them. The 'wise men' and 'the scribes' are almost certainly the same group (see Orton 1988). Matthew 13:52 also alludes to a Christian scribe: this person has been 'discipled' for the kingdom of heaven. I am now inclined to accept the traditional view that this is the evangelist's own self-portrait at the centre-point of his Gospel - it is like an artist's signature in a corner of her or his painting.

Christian scribal activity is implied by the references to 'binding and loosing' at Matthew 16:19 and Matthew 18:18. In Jewish communities one of the scribe's tasks was to pronounce on the interpretation of the law, that is, what is still binding and what is not. So too within Matthean Christian communities: God's will (as expressed particularly in the sayings of Jesus) had to be discerned. In Matthew 16:19 and Matthew 18:18, however, authority to do this is given to Peter and to the whole community, not to one particular group.

Within Matthean communities special ministries were exercised by three groups: prophets, the righteous, and 'wise men and scribes.' No doubt these groups were not mutually exclusive: some prophets may also have been scribes. As Eduard Schweizer (1983:140) has noted, 'there is not the slightest indication of a specially emphasized ministry to which certain things are reserved that not every community member can do'. In making that comment Schweizer was referring to chapter 18 , the 'church order' discourse. In my view his comments are a fair summary of the very limited evidence Matthew's gospel as a whole gives us concerning ministry.

In none of the passages referred to is there a suggestion that these groups enjoyed a particular status or used titles of honour. This observation is confirmed by Matthew 23:8-12: in contrast to synagogue communities, followers of Jesus are not to be concerned with status or titles of honour. 'The greatest among you must be your servant' (Mt 23:11).

However it would be rash to conclude from these passages that Matthew's communities were egalitarian, without any structures at all. Down through the centuries Christian groups have criticized other Christians for their alleged failure to put Mat- 
thew 23:8-12 into practice, but in fact within their own circles the critics themselves have often had strongly hierarchical patterns of leadership ${ }^{18}$. Autocratic leaders have often claimed to be the servant of the whole community!

In the early decades of the second century the term oi $\mu$ iko oi seems to have survived only in the circles in which the Nag Hammadi Apocalypse of Peter and 5 Ezra were written (see Stanton 1992a:256-277). There are a number of references to Christian prophets in this period, but Christian 'righteous' and 'wise men and scribes' seem to have disappeared.

Within a generation or so Matthew's gospel was used by the compiler of the Didache. In several respects the ethos of the Didache echoes that of Matthew's gospel, but it contains an almost completely different set of terms for Christian groups and leaders.

The references in Didache 11-13 to itinerant teachers, apostles, and prophets are intriguing. Are we to assume that these three groups were quite distinct? Or are we to assume that while all true apostles were prophets (as is implied in 11:4-5), the reverse was not the case? Were all prophets also teachers, as 13:2 implies? Apostles appear only in 11:3-6. This passage refers briefly to their welcome, permitted short stay in the community, and their departure, but nothing is said about their role in local community life. There is no suggestion (except in the later title of the Didache) that the apostles were identical with the twelve disciples of Jesus. If, as in Paul's day, apostles were primarily missionaries who established communities and then moved on to eyangelise other areas, this would account for the failure of Didache 13-15 to say anything about their role in community life. Or perhaps by the time of the final compilation of the Didache the apostles' hey-day was over.

In the Didache prophets are discussed much more fully than apostles and teachers. They can exercise freedom in leading worship (10:7). The marks of true and false prophets are set out at some length (11:7-12). Prophets are 'your high priests' (13:2) and are to be supported when they decide to settle in the community (13:1-7).

Didache 15.1 refers to the choice of 'bishops and deacons', who, apparently, are not itinerant. The same phrase is used in Phil 1:1, but not otherwise in the New Testament. The community addressed by the Didache is encouraged strongly to be evenhanded in its treatment of itinerant teachers, apostles, and prophets on the one hand, and its own 'settled' bishops and deacons: both groups are to be given the same respect, for their ministry is similar. This may suggest that the choice of local 'settled' bishops and deacons is a recent innovation, perhaps to counter the influence of wandering charismatic prophets. 
The Didache assumes that a Christian community may have several bishops who share leadership with teachers, apostles, prophets, and deacons; there is no trace here of the single pre-eminent bishop whose importance is stressed strongly by Ignatius in about AD 100.

The disappearance of Matthew's terminology and the use of a largely different set of terms in the Didache is baffling. The different genre of Matthew and the Didache provides part of the answer. Unlike the compiler of the Didache, Matthew has written a gospel: his primary purpose is to set out the story and significance of Jesus for his readers, not to give a full account of ministry within the communities to which he is writing. We are given no more than a few hints concerning the self-understanding of Matthean communities and the terminology used to refer to groups of disciples.

\section{$4.2 \dot{\alpha}$ vopia}

In numerous passages erring or unfaithful disciples are roundly condemned. For example, in Matthew 7:19 disciples are warned that those who do not bear good fruit will be cut down and thrown into the fire. In the pericope which follows judgement is pronounced on those whose deeds are evil (Mt 7:23). In the explanation of the parables of the weeds (Mt 13:36-43), a passage in which the evangelist's own hand is clearly evident, unfaithful disciples are in view: the 'sons of the evil one' are evildoers who will be thrown into the furnace of fire at the close of the age. In Matthew 24:51 the evangelist makes a redactional change to the $Q$ tradition he is using and stresses that unfaithful disciples will share judgement with 'the hypocrites', that is, with the scribes and Pharisees on whom judgement is pronounced in chapter 23. In short, Matthew is as ferocious in his denunciation of his fellow-disciples as he is of the Jewish religious leaders.

Is it possible to say more about the 'heretical' views of some members of Matthew's communities? Many Matthean specialists have accepted Gerhard Barth's view that the evangelist is 'fighting on two fronts', that is, that he is opposing both the leaders of contemporary Judaism and antinomian heretics in his own communities (Bornkamm, Barth \& Held 1963:62-76, 159-164). Barth claims that Matthew's emphasis on the abiding validity of the law in Matthew 5:17-19, Matthew 7:15-20 and Matthew 24: 11-13 is directed at antinomian opponents who can best be described as Hellenistic libertines; they are the false prophets of Matthew 7:15 and Matthew 24:11.

While Matthew clearly levels harsh criticisms at disciples - and by implication at his readers, I am not persuaded that he is attacking one particular 'heretical' group. In his composite picture of the opponents Barth appeals to several passages and themes. Matthew uses $\dot{\alpha} \nu$ pi $\alpha$ three times to refer to disciples (Mt 7:23; 13:41; 24:12). These 
are general references to disobedience to the 'will of the Father' and are not to be limited to antinomians. Matthew's warnings about false prophecy do not go beyond the similarly indefinite comments about heresy which we find in passages such as 1 Timothy 6:3-5; Titus 1:16 and Didache 11:1-8 (Strecker 1962:137, note 4; see also Davison 1985:617-635).

The points I made above concerning genre and geography 'make this view even more plausible. Since Matthew is writing a gospel, not a letter, we should not expect an explicit repudiation of a particular false view. And since he is writing to a cluster of communities, with at least some of which he may not have had a close relationship, he is much more likely to be making general points about erring followers of Jesus than to be attacking a 'heresy'.

I have argued that we should take the genre of Matthew seriously and be wary of attempts to link the gospel to a precise set of social, historical or religious circumstances. We do not know as much about Matthew's communities as we would like, but we know enough about the evangelist's purposes and the 'horizons of expectation' of the initial recipients to enable us to read the text sensitively.

The point at which any text ends is crucial. Matthew's gospel is no exception nor is this paper. In Matthew's final sentence, the disciples are told to go from the mountain in Galilee where they had met Jesus, and make disciples of all nations. How are they to do this? By baptizing in the triadic name, and by teaching people to observe all the commands Jesus had given them. The commands of Jesus are set out fully in Matthew's Bios of Jesus, which he refers to as 'this gospel' in 24:14 and 26:13 (cf also 13:19). So for Matthew's communities, the text of this gospel is to be central in their 'discipling of the nations': text and context are linked inextricably.

* This article.was previously published in the SBL Seminar Papers (1994), edited by E H Lovering. Atlanta: Scholars Press.

\section{End Notes}

1 Allison (1992:1203-1222) and Standaert (1992:1223-1250) also accept that Matthew should be read as an ancient biography.

2 For discussion of earlier proposals, see Stanton (1984:1941-1942).

3 See also White (1991:211-247). White plausibly suggests that Matthew may have come from 'a Syro-Phoenician arc from Upper Galilee northward to Coele-Syria' (White 1991:229). However, I am not persuaded by his suggestion that we can pinpoint a particular political and religious crisis as the fons et origo of the gospel.

4 Although the recently excavated villa at Sepphoris dates from the first decades of the third century, it also supports the general point I am making (Meyers, Netzer \& Meyers 1992; see also Wallace-Hadrill 1994; Murphy-O'Connor 1983:161-168). 
5 For a fuller discussion, see Stanton (1996b).

6 In a letter to me dated 6 October 1992, Sjef van Tilborg of Nijmegen makes a similar point, but without reference to Justin. 'If this plurality of communities is a historically correct supposition, one can imagine that the troubles with violent and opposing Jews are not the same at all places and at the same time. Matthew would then be an author who is aware of a very delicate situation ... He knows that some group(s) have departed from synagogue(s), but that others remained connected to or at least in close contact with the synagogue(s) and the leaders. He is writing for readers in different situations who do not know exactly where they stand; whether they have separated; whether they have to go; whether they should stay notwithstanding the troubles they are confronted with et cetera .... What I want to say is that Matthew with his gospel gives the arguments to leave, but he does not reject the communities which did not (and/or do not) take that decision'.

7 Although Saldarini (1994:37) correctly stresses that the crowds are fundamentally friendly, but unreliable, their roles are even more diverse than he suggests (see esp Carter 1993:54-67).

8 Carter (1993:65) makes the same point, but only in passing.

9 This is an allusion to Justin's earlier report of his encounter with a venerable old man through whom he is introduced to Christian claims.

10 These charges and counter-charges of 'false prophecy' and 'leading astray' have deep roots in early Christian-Jewish polemic and apologetic (see Stanton 1992a:237-242; 1994a:166-182).

11 See Dialogue $9.1 ; 36.2 ; 38.1-2 ; 43.5 ; 48.2 ; 62.2 ; 68.7 ; 71.1 ; 110.1 ; 112.4-5 ; 117.4 ; 120.5$; $133.3 ; 134.1 ; 137.2 ; 140.2 ; 142.2$.

12 In addition to the literature cited by Meeks and Saldarini, see also Johnston (1943). The linguistic evidence is discussed fully in chapter III, page 35-45.

13 Saldarini (1994:118) notes that é $\kappa \kappa \lambda \eta \sigma i \alpha$ is used most frequently of 'Christian' assemblies outside Israel and Syria. Only the author of Acts ises the term of mid first-century believers-in-Jesus in Jerusalem and Antioch and his usage may be anachronistic'. This point is undermined by Galatians 1:22.

14 For a full discussion of the threefold accusation that Jesus is in league with the prince of demons (Mt 9:34; 10:25; 12:24, 27), see Stanton (1992a:169-191).

15 Matthew takes the phrase from Mark 9:42, the only place in Mark where it is used metaphorically of the disciples. As in many other passages, Matthew takes over a phrase from Mark and uses it himself several times in key passages (see Stanton 1994:326-345).

16 A number of MSS do have 'believe in me' at Mark 9:42, but I take this reading to be a harmonisation of the Matthean tradition.

17 Luz speculates that at the pre-Matthean stage they may have been a special group of devout disciples, perhaps wandering ascetics who were not prophets. 
18 I am grateful to my colleague Dr. Francis Watson for reminding me of this. My colleagues Prof. Leslie Houlden and Dr. Judith Lieu and members of our New Testament research seminar at King's College, London, made a number of helpful comments on an earlier version of this paper.

\section{Works Consulted}

Allison, D C 1992. Matthew: Structure, Biographical Impulse and the Imitatio Christi, in Van Segbroeck et al 1992:1203-1222.

Anderson, J C 1993. Response at the 1993 SBL Meeting to Dennis Duling, Matthew and marginality, in Lovering, E H, SBL 1993 Seminar Papers, 642-671. Atlanta: Scholars Press. (= HTS 51/2, 1995, pp 358-387.)

Aune, D 1988. The New Testament in Its Literary Environment. London: James Clarke.

Avigad, N 1991. The Herodian Quarter in Jerusalem. Jerusalem: Keter.

Balch, D L (ed) 1991. Social History of the Matthean Community: Cross-disciplinary Approaches. Minneapolis: Fortress Press.

Bornkamm, G, Barth, G \& Held, H J 1963. Tradition and Interpretation in Matthew. London: SCM Press.

Burridge, R A 1992. What are the Gospels? A Comparison with Graeco-Roman Biography. Cambridge: Cambridge University Press.

Carter, W 1993. The Crowds in Matthew's Gospel. CBQ 55, 54-67.

Davies, W D \& Allison, D C 1988. A Critical and Exegetical Commentary on the Gospel according to Matthew, Volume One. Edinburgh: T \& T Clark.

- 1991 A Critical and Exegetical Commentary on the Gospel according to Matthew, Volume Two. Edinburgh: T \& T Clark.

Davison, J E 1985. Anomia and the Question of an Antinomian Polemic in Matthew. JBL 104, 617-635.

Johnston, G 1943. The Doctrine of the Church in the New Testament. Cambridge: Cambridge University Press.

Kingsbury, J D 1991. Conclusion: Analysis of a Conversation, in Balch 1991:259269.

Luz, U 1985. Das Evangelium nach Matthäus, 1. Teilband: Mt 1-7. NeukirchenVluyn: Neukirchener Veriag.

- 1983. Disciples, in Stanton, G N (ed), The Interpretation of Matthew, 98128. London: SPCK.

Meeks, W A 1983. The First Urban Christians. London: Yale.

Meier, J P 1991. Matthew and Ignatius: A Response to William R Schoedel, in Balch 1991:178-186.

Meyers, E M, Netzer, E \& Meyers, C L 1992. Sepphoris. Winona Lake: Eisenbrauns. 
Murphy-O'Connor, J 1983. St. Paul's Corinth: Texts and Archaeology. Collegeville: Michael Glazier.

Orton, D E 1988. The Understanding Scribe. Sheffield: JSOT Press.

Overman, J A 1990. Matthew's Gospel and Formative Judaism: The Social World of the Matthean community. Minneapolis: Fortress Press.

Rey-Coquais, J-P 1992. 'Decapolis', in Anchor Bible Dictionary II, 118. New York: Doubleday.

Saldarini, A J 1994. Matthew's Christian-Jewish community. Chicago: Chicago University Press.

Schweizer, E 1983. Matthew's Church, in Stanton, G N (ed), The Interpretation of Matthew. London: SPCK.

Segal, A F 1991. Matthew's Jewish Voice, in Balch 1991:3-37.

Standaert, B 1992. L'evangile selon Matthieu, in Van Segbroeck et al 1992:12231250.

Stanton, G N 1984. The Origin and Purpose of Matthew's Gospel: Matthean Scholarship from 1945-1980. ANRW II 25/3, 1941-1942.

- 1992a. A Gospel for a New People: Studies in Matthew. Edinburgh: T \& T Clark.

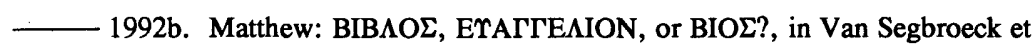
al 1992:188-1201.

1992c. The Communities of Matthew. Interp. 46, 371-391.

- 1994a. Jesus of Nazareth: A Magician and False Prophet who Deceived God's People?, in Green, J B \& Turner, M M B (eds), Jesus of Nazareth: Lord and Christ, 166-182. Grand Rapids: Eerdmans.

- 1994b. Early Objections to the Resurrection of Jesus', in Barton, S C \& Stanton, G N (eds), Resurrection: Essays in Honour of $J$ L Houlden. London: SPCK.

1996a. 'Ministry' in Matthean Christianity: In The Call to Serve, in Campbell, D A (ed), Biblical and Theological Perspectives on Ministry. In Honour of Bishop Penelope Jamieson. Sheffield: Scheffield Academic Press.

- 1996b. Justin Martyr's Dialogue with Trypho: Group Boundaries, 'Proselytes', and 'God-fearers', in Stanton, G N \& Stroum, G (eds), Tolerance and Intolerance in Early Judaism and Early Christianity. Cambridge: CUP.

Strecker, G 1962. Der Weg der Gerechtigkeit. Göttingen: Vandenhoeck \& Ruprecht. (FRLANT 82.)

Van Segbroeck, F et al (eds) 1992. The Four Gospels, II. Leuven: University Press and Peeters. 
Wallace-Hadrill, A 1994. Houses and society in Pompeii and Herculaneum. Princeton: Princeton University Press.

White, L M 1991. Crisis Management and Boundary Maintenance: The Social Location of the Matthean Community, in Balch 1991:211-247. 